\title{
PELAKSANAAN METODE BRAINSTORMING DENGAN PENUGASAN UNTUK MENINGKATKAN PRESTASI BELAJAR GEOGRAFI SISWA KELAS XI.IPS 1 SMA NEGERI 1 KUTA
}

\section{IMPLEMENTATION OF BRAINSTORMING METHOD WITH ASSIGNMENT TO INCREASE GEOGRAPHY LEARNING ACHIEVEMENT STUDENTS OF CLASS XI.IPS 1 SMA NEGERI 1 KUTA}

\author{
I Made Gunawan* \\ SMA Negeri 1 Kuta, Badung, Bali, Indonesia \\ *Email Penulis korespondensi: madegunawan7109@gmail.com
}

\begin{abstract}
Abstrak
Tujuan melakukan penelitian tindakan kelas ini adalah untuk meningkatkan prestasi belajar geografi siswa kelas XI.IPS 1 semester II tahun pelajaran 2019/2020 di SMA Negeri 1 Kuta dengan pelaksanaan metode brainstorming dengan penugasan. Penelitian ini dilakukan terhadap 36 subjek penelitian. Cara yang dilakukan adalah menambah gaya pembelajaran lama yang konvensional menjadi cara pembelajaran baru yang bersifat penemuan menggunakan pelaksanaan metode brainstorming dengan penugasan. Penelitian dilakukan dalam dua siklus yang masing-masing siklusnya dilakukan dengan tahapan perencanaan, pelaksanaan, observasi dan refleksi. Untuk mengumpulkan data hasil penelitian digunakan tes prestasi belajar dan untuk menganalisis datanya digunakan analisis deskriptif. Dilihat dari hasil evaluasi yang telah dilakukan terjadi peningkatan dari data awal dengan rata-rata 66,06 dengan ketuntasan belajar 38,89\%, pada siklus I rata-ratanya meningkat menjadi 69,86 dengan ketuntasan belajar $72,22 \%$. Pada siklus II rata-ratanya meningkat menjadi 81,14 dengan ketuntasan belajar 100\%. Dengan demikian dapat disampaikan simpulan bahwa pelaksanaan metode brainstorming dengan penugasan dapat meningkatkan prestasi belajar Geografi.
\end{abstract}

Kata-Kata Kunci: Metode Brainstorming; Pendekatan Ilmiah; Prestasi Belajar

\begin{abstract}
The purpose of conducting this classroom action research is to improve the learning achievement of geography students of class XI.IPS 1 semester II for the 2019/2020 school year at SMA Negeri 1 Kuta by implementing the brainstorming method with assignments. This research was conducted on 36 research subjects. The way to do this is to add the old conventional learning style to a new learning method that is discovery using the implementation of the brainstorming method with assignments. The research was conducted in two cycles, each cycle carried out with stages of planning, implementation, observation and reflection. To collect research data used achievement test and to analyze the data used descriptive analysis. Judging from the results of the evaluation that has been carried out, there is an increase from the initial data with an average of 66.06 with $38.89 \%$ learning completeness, in the first cycle the average increases to 69.86 with $72.22 \%$ learning completeness. In the second cycle the average increased to 81.14 with $100 \%$ learning completeness. Thus, it can be concluded that the implementation of the brainstorming method with assignments can improve learning achievement in geography.
\end{abstract}

Keywords: Brainstorming Method; Scientific Approach; Learning Achievement

\section{PENDAHULUAN}

Dalam menulis latar belakang masalah perlu dipahami kesenjangan antara kondisi harapan dengan kondisi yang sebenarnya ada di lapangan. Kondisi harapan terletak pada terjadinya peningkatan yang diupayakan lewat berbagai cara termasuk pemahaman guru terhadap model yang digunakan. Menurut H.D. Iriyanto (2012:44) bahwa pendidikan bukanlah seperti mengisi ember kosong, tetapi seperti menyalakan api yang hampir padam. Kesuksesan karier itu lebih bergantung pada kemampuan seseorang memahami diri sendiri, 
kemampuan mengelola diri sendiri secara efektif, kemampuan untuk memahami orang lain dan kemampuan untuk mengelola hubungan dengan orang lain. Tugas seorang guru yang sesungguhnya bukanlah menyiapkan mereka agar menguasai ilmu pengetahuan, keterampilan dan kematangan pribadi yang dibutuhkan untuk meraih keselamatan dan kematangan pribadi yang dibutuhkan untuk meraih keselamatan dan kebahagiaan hidup.

Menurut Sofyan (2013 : 53) PBM merupakan inti dari proses pendidikan secara keseluruhan dengan pendidik sebagai pemegang peranan utama. PBM adalah fenomena yang kompels. Segala sesuatunya berarti - setiap kata, pikiran tindakan dan asosiasi - sejauhmana pendidik mengubah lingkungan, presentasi dan rancangan pengajaran, sejauh itu pula PBM berlangsung.

Sofyan Amri (2013 : 219) selanjutnya menjelaskan bahwa pendidikan memiliki arti yang beragam yaitu : 1) Pendidikan ialah proses perubahan sikap dan tata laku seseorang atau kelompok orang dalam usaha mendewasakan manusia melalui upaya pengajaran dan pelatihan (Kamus Besar Bahasa Indonesia, 1991); 2). Dalam pengertian sempit pendidikan berarti perbuatan atau proses perbuatan untuk memperoleh pengetahuan; 3) Pendidikan ialah segala pengalaman belajar yang berlangsung dalam segala lingkungan dan sepanjang hidup serta pendidikan dapat diartikan sebagai pengajaran yang diselenggarakan di sekolah sebagai lembaga pendidikan formal.

H. Martinis Yamin dan Jamilah Sabri Sanan (2013: 30-32) menjelaskan bahwa guru sebagai tenaga profesional bertugas merencanakan, melaksanakan, menilai, membimbing, melatih, melakukan penelitian, memenuhi standar kompetensi. Guru wajib menciptakan suasana pendidikan yang bermakna, menyenangkan, kreatif, dinamis, dialogis, berkomitmen meningkatkan mutu pendidikan, memberi tauladan, menjaga nama baik lembaga. Guru berperan untuk mampu melakukan interaksi, pengasuhan, mengatur tekanan, memberi fasilitas, perencanaan, pengayaan, menangani masalah, membimbing dan memelihara.

Dari semua harapan yang telah disampaikan, ternyata kebenaran yang ada di lapangan jauh berbeda yaitu: nilai geografi siswa kelas XI.IPS 1 semester II tahun pelajaran 2019/2020 di SMA Negeri 1 Kuta baru mencapai rata-rata 66,06 dengan ketuntasan belajar baru mencapai $38,89 \%$. Kendala-kendala yang ada yaitu: 1) Siswa kebanyakan pasif karena tidak ada tugas yang harus dikerjakan, 2) Siswa terlihat bosan akibat guru terus berceramah, 3) Siswa tidak mampu menguasai materi, 4) Guru masih mengajar dengan pola lama dan 5) Guru belum melaksanakan pembelajaran yang kooperatif dan kolaboratif.

Prestasi belajar yang rendah tersebut merupakan masalah pembelajaran di sekolah ini sehingga peneliti sebagai seorang guru harus mengupayakan cara untuk bisa mengatasinya. Untuk itu dipilihlah pelaksanaan metode brainstorming dengan penugasan sebagai upaya untuk menyelesaikannya. Hal di atas merupakan masalah pembelajaran yang terjadi di sekolah ini yang harus segera dibenahi oleh karenanya penelitian ini perlu segera diupayakan agar masalah tidak berlarut-larut. Model yang dipilih tersebut adalah hasil konsultasi dengan teman-teman guru sejawat setelah bersama-sama mempelajari secara seksama kebenaran teori yang ada.

Mengacu pada apa yang dipaparkan dalam latar belakang, maka rumusan masalah yang dapat disampaikan: Apakah pelaksanaan metode brainstorming dengan penugasan akan dapat meningkatkan prestasi belajar geografi siswa kelas XI.IPS 1 semester II tahun pelajaran 2019/2020 di SMA Negeri 1 Kuta?

Tujuan penelitian tindakan kelas adalah: Untuk mengetahui seberapa tinggi terjadinya peningkatan prestasi belajar geografi siswa kelas XI.IPS 1 semester II tahun pelajaran 2019/2020 di SMA Negeri 1 Kuta setelah pelaksanaan metode brainstorming dengan penugasan. 
Manfaat penelitian tindakan kelas antara lain: 1) Dapat meningkatkan kualitas pembelajaran, peningkatan kinerja guru, proses pemecahan masalah pembelajaran. 2) Mampu menanamkan kepuasan pada diri guru selaku peneliti dan rasa percaya diri, sehingga guru memiliki modal untuk terus menerus mengembangkan model-model baru yang inovatif. 3) Dengan dilakukannya penelitian ini akhirnya secara khusus bagi peserta didik akan terpetik keuntungan-keuntungan seperti: keuntungan memperoleh cara belajar, keuntungan memahami model-model baru, keuntungan memahami strategi pembelajaran baru.

Walaupun peneliti bisa memahami apa yang dibahas, namun dalam sebuah karya ilmiah harus mengemukakan pendapat-pendapat pakat dan bukan terus berdasarkan pendapat sendiri.

Brainstorming ialah suatu teknik atau cara mengajar yang dilaksanakan oleh guru di dalam kelas. Metode ini dilakukan dengan melontarkan suatu masalah ke siswa oleh guru, kemudian siswa menjawab atau menyatakan pendapat, atau komentar sehingga mungkin masalah tersebut berkembang menjadi masalah baru. Metode ini dapat diartikan pula sebagai satu cara untuk mendapatkan banyak ide dan sekelompok manusia dalam waktu yang sangat singkat (Aqib, 2014: 118).

Istilah yang relatif baru diperkenalkan dalam metode pendidikan orang dewasa adalah curah pendapat (brainstorming). Curah pendapat adalah salah satu bentuk berpikir kreatif sehingga pertimbangan memberikan jalan untuk berihisiatif kreatif. Peserta didorong untuk mencurahkan semua ide yang timbul dari pikirannya dalam jangka waktu tertentu berkenaan dengan beberapa masalah, dan tidak diminta untuk menilainya selama curah pendapat berlangsung. Penilaian akan dilakukan pada periode berikutnya di mana semua ide dipilih, dievaluasi, dan mungkin diterapkan (Suprijono, 2013: 122).

Metode brainstorming adalah suatu bentuk diskusi dalam rangka menghimpun gagasan, pendapat, informasi, pengetahuan, pengalaman, dari semua peserta. Berbeda dengan diskusi, dimana gagasan dari seseorang dapat ditanggapi (didukung, dilengkapi, dikurangi, atau tidak disepakati) oleh peserta lain, pada penggunaan metode curah pendapat pendapat orang lain tidak untuk ditanggapi. Tujuan curah pendapat adalah untuk membuat kompilasi (kumpulan) pendapat, informasi, pengalaman semua peserta yang sama atau berbeda. Hasilnya kemudian dijadikan peta informasi, peta pengalaman, atau peta gagasan (mindmap) untuk menjadi pembelajaran Bersama (Nyoto dan Wena, 2014: 39).

Lima strategi sumbang saran yang berbeda dijelaskan oleh Flowers di bawah ini, yaitu: Strategi individu, Seluruh kelas, Kelompok kecil, Relay, Round robin (http://jcflowers1.iweb.bsu.edu/rlo/brainstorming1.htm).

Menurut Sukadi (2015:4) kelebihan metode brainstorming antara lain: 1) Susana disiplin dan demokratis dapat tumbuh, 2) Anak-anak aktif untuk menyatakan pendapatnya, 3) Melatih siswa untuk berfikir dengan cepat dan tersusun logis, 4) Merangsang siswa untuk selalu berpendapat yang berhubungan dengan masalah uang diberikan oleh guru, 5) Terjadi persaingan yang sehat, 6) Meningkatkan partisipasi siwa dalam menerima pelajaran, 7) Siswa yang kurang aktif menapat bantuan dari temannya yang pandai atau dari guru. Sedangkan kelemahan metode brainstorming antara lain: 1) Guru kurang memberi waktu kepada siswa untuk berfikir yang baik, 2) Anak yang kurang selalu ketinggalan, 3) Kadang-kadang pembicaraan hanya dimonopoli oleh anak yang pandai, 4) Guru hanya menampang pendapatpendapat tidak pernah merumuskan kesimpulan.

Metode penugasan adalah suatu cara penyajian pelajaran dengan cara guru memberi tugas tertentu kepada siswa dalam waktu yang telah ditentukan dan siswa mempertanggungjawabkan tugas yang dibebankan kepadanya (Fauzi Usman, 2012 : 125). Metode tugas adalah metode penyajian bahan dimana guru memberikan tugas tertentu agar 
siswa melakukan kegiatan belajar. Tugas dan rersitasi merangsang siswa untuk aktif belajar baik secara individu maupun kelompok (dikutif dari Siti Masyitoh: 2015:12).

Agar pemberian tugas memberikan efek yang baik, maka guru dalammemberikan tugas perlu memperhatikan, mengarahkan dan membimbing siswa sehingga maksud dan tujuan yang telah ditetapkan dapat dicapai secara efektif dan efisien. Adapun maksud dan tujuan pemberian tugas antara lain: 1) Untuk memelihara dan memantapkan tingkah laku yang telah dipelajari, 2) Untuk melatih keterampilan, konsep, dan prinsip yang baru saja dikembangkan untuk memperoleh pengertian yang lebih dalam tentang konsep itu, 3) Untuk mengingatkan kembali dan memelihara topik-topik yang telah dipelajari sebelumnya.

Menurut Sukadi (2015: 138) pemberian tugas mempunyai maksud dan tujuan sebagai berikut: 1) Latihan dan keterampilan, serta untuk menambah kecepatan belajar dan keakuratan belajar. 2) Membaca, meresapkan, dan meringkas apa yang dipelajari. 3) Mendorong siswa untuk bertanggung jawab terhadap pelajaran. 4) Mengembangkan belajar mandiri.

Menurut Tim Instruktur PKG SMA, pemberian tugas perlu memperhatikan prinsipprinsip umum antara lain: 1) Tugas harus bermotivasi baik. 2) Tugas harus bersifat diagnostik. 3) Tugas jangan terlalu banyak. 4) Jangan memberikan tugas mengenai teknik yang baru dikembangkan yangbelum dikerjakan di kelas. 5) Merupakan ide yang baik jika pada saat tertentu kita menyampaikan skill-skill yang telah dipelajari sebelumnya.

Istilah prestasi belajar dalam dunia pendidikan menjadi sesuatu hal yang menarik untuk dibahas, karena keberadaannya sangat bermnfaat bagi pendidik, peserta didik, maupun orang tua. Prestasi belajar bagi pendidik dapat dijadikan tolok ukur tentang sejauh mana keberhasilan kegiatan pembelajaran yang sudah dilakukan terhadap peserta didiknya.

Sutratinah Tirtonegoro (2015: 43) menyebutkan bahwa prestasi belajar adalah hasil dari pengukuran serta penilaian usaha belajar. Memberi batasan prestasi belajar yaitu hasil usaha kegiatan belajar yang dinyatakan dalam bentuk simbol-simbol, huruf atau kalimat yang sudah dicapai oleh setiap peserta didik dalam setiap periode tertentu.

Prestasi belajar adalah isi dan kapasitas seseorang. Maksudnya adalah hasil yang diperoleh seseorang setelah mengikuti pendidikan ataupun pelatihan tertentu. Ini bisa ditentukan dengan memberikan tes pada akhir pendidikan itu. Habsari (2015: 75) menyatakan bahwa yang dimaksud dengan prestasi belajar adalah hasil yang dicapai dalam suatu usaha (belajar) untuk mengadakan perubahan atau mencapai tujuan.

Adapun prinsip-prinsip belajar menurut Thursan Hakim (2015: 2-10) adalah: 1) Belajar harus berorientasi pada tujuan yang jelas. Dengan menetapkan suatu tujuan yang jelas, setiap orang akan dapat menentukan arah dan juga tahap-tahap belajar yang harus dilalui dalam mencapai tujuan belajar tersebut. 2) Proses belajar akan terjadi bila seseorang dihadapkan pada situasi problematis. Sesuatu yang bersifat problematis (mengandung masalah dengan tingkat kesulitan tertentu), akan merangsang seseorang untuk berpikir dalam memecahkannya. Oleh karena itu, setiap guru yang baik akan memberikan pelajaran mungkin kepada murid-muridnya menghadapkan mereka dengan sesering pada situasi yang mengandung problematis. 3) Belajar dengan pengertian akan lebih bermakna daripada belajar dengan hafalan. Belajar dengan pengertian lebih memungkinkan seseorang untuk lebih berhasil dalam menerapkan dan mengembangkan segala hal yang sudah dipelajari dan dimengertinya. Walaupun umpamanya pelajaran yang dihafalkannya itu berjumlah sangat banyak, ia akan kurang bisa menerapkan dan mengembangkannya menjadi suatu pemikiran baru yang lebih bermanfaat. 4) Belajar merupakan proses yang kontinu. Belajar merupakan suatu proses yang tentu saja memerlukan waktu. Karena itu, belajar harus dilakukan secara kontinu di dalam jadwal waktu tertentu dengan jumlah materi yang sesuai dengan kemampuan kita. 5) Belajar memerlukan kemauan yang kuat. Hal yang sering 
menjadi masalah adalah bagaimana membuat kemauan belajar itu kuat dan stabil? Untuk menjawab pertanyaan ini kita harus kembali pada prinsip belajar yang pertama, yaitu belajar harus mempunyai tujuan yang jelas. Tujuan yang jelas dan benar-benar diingini seseorang, akan menyebabkan orang tersebut selalu berusaha untuk belajar dengan rajin agar apa yang menjadi tujuannya itu tercapai. 6) Keberhasilan belajar ditentukan oleh banyak faktor. Faktor-faktor yang mempengaruhi atau menentukan keberhasilan belajar itu banyak. Ada kalanya juga individu yang satu memerlukan faktor yang berbeda daripada individu lain di dalam mencapai keberhasilan belajar. Secara garis besar, faktor-faktor yang mempengaruhi keberhasilan belajar itu dapat kita bagi menjadi dua bagian: faktor internal dan faktor eksternal. 7) Belajar secara keseluruhan akan lebih berhasil daripada belajar secara terbagibagi. Prinsip belajar di atas memang memerlukan penjelasan yang agak panjang. Jika kita belajar secara keseluruhan, kita akan dapat melihat dan mengerti dengan jelas bagaimana unsur-unsurb yang merupakan bagian dari keseluruhan itu berhubungan membentuk satu keseluruhan atau kebulatan. Cara belajar seperti ini akan memungkinkan seseorang untuk dapat mengerti suatu pelajaran dengan lebih cepat dan mudah. 7) Proses belajar memerlukan metode yang tepat. Adakalanya seorang siswa atau mahasiswa mengalami kesulitan walaupun ia telah mengerahkan seluruh tenaga dan pikiran untuk belajar. Pemahaman yang didapatnya tetap saja sedikit sekali. Jelaslah bahwa dalam hal ini telah terjadi ketidakseimbangan antara tenaga dan pikiran yang telah dikerahkan untuk belajar dengan hasil belajar yang didapat. Karena itu, proses belajar memerlukan metode yang tepat agar masalah tersebut dapat dihindari. 8) Belajar memerlukan adanya kesesuaian antara guru dan murid. Di dalam prinsip belajar ini, sengaja tidak kami katakan bahwa belajar itu memerlukan guru yang baik, karena kriteria guru yang baik itu relatif sifatnya. Kesesuaian antara guru dan murid, kenyataannya, memang sangat mernpengaruhi seorang murid dalam menyenangi suatu pelajaran. Hal ini tentu saja akan mempengaruhi motivasi murid dalam belajar. Karena itu, guru yang baik tentunya akan selalu berusaha untuk menerapkan metode pengajaran yang benar-benar sesuai dengan kemampuan murid-muridnya. 9) Belajar memerlukan kemampuan dalam menangkap intisari pelajaran itu sendiri. Belajar dengan penuh pengertian itu jauh lebih baik dan bermakna daripada belajar dengan menghafal. Seseorang yang telah berhasil mendapatkan pengertian yang mendalam dalam suatu proses belajar berarti telah mampu menangkap intisari pelajaran yang telah dipelajarinya. Kemampuan menangkap intisari pelajaran, sangat perlu dimiliki siswa atau mahasiswa. Dengan cara ini, siswa atau mahasiswa akan dapat membuat suatu ringkasan atau ikhtisar dari semua mata pelajaran yang dipelajarinya. Dengan demikian, materi pelajaran yang tadinya terasa banyak dan berat akan terasa lebih sedikit, ringan, dan mudah untuk dipelajari (Hakim, 2015:2-10).

Ciri-ciri umum kegiatan belajar menurut Aunurrahman (2017:36-37) sebagai berikut: 1) Belajar menunjukan suatu aktivitas pada diri seseorang yang disadari atau disengaja. Oleh karena itu, pembelajar harus dengan sengaja dan sadar merencanakannya dalam bentuk kegiatan tertentu. 2) Belajar merupakan interaksi individu dengan lingkungannya. Lingkungan dapat berupa manusia atau objek-objek tertentu yang memungkinkan pembelajar memperoleh pengalaman atau pengetahuan baru dan bisa juga pengetahuan lama yang menimbulkan perhatian kembali dan dapat menyebabkan terjadinya interaksi. 3) Hasil belajar ditandai dengan perubahan tingkah laku walaupun tidak semua perubahan tingkah laku merupakan hasil belajar, akan tetapi aktivitas belajar umumnya disertai perubahan tingkah laku yang dapat diamati (observable).

Bhakti (2017: 36) menyatakan bahwa prestasi belajar dipengaruhi oleh faktor intern dan faktor ekstern. Faktor intern yang dialami dan dihayati siswa yang berpengaruh terhadap proses belajar adalah: a). sikap siswa terhadap proses belajar, 2) motivasi belajar, 3) 
konsentrasi belajar, 4) kemampuan mengolah bahan ajar, 5) kemampuan menyimpan perolehan hasil belajar, 6) kemampuan menggali hasil belajar yang telah disimpan, 7) kemampuan untuk berprestasi atau unjuk hasil belajar, 8) rasa percaya diri siswa, intelegensi,keberhasilan belajar dan kebiasaan belajar. Faktor ekstern yang mempengaruhi prestasi belajar antara lain: 1) guru sebagai pembimbing belajar siswa, 2) sarana dan prasarana belajar, 3) kondisi pembelajaran, 4) kebijaksanaan penilaian, 5) kurikulum yang diterapkan dan lingkungan sosial siswa.

\section{METODE PENELITIAN}

Sehubungan dengan ditemukannya masalah rendahnya prestasi belajar geografi pada kelas XI.IPS 1 semester II tahun pelajaran 2019/2020 di SMA Negeri 1 Kuta, maka penelitian tindakan kelas ini dilakukan di lokasi tersebut. Sekolah ini beralamat di jalan Dewi Saraswati Seminyak - Kuta, Telp./Fax (0361) 737 925. Sekolah tempat dilaksanakan penelitian sangat aman dan nyaman untuk mendukung pelaksanaan proses pembelajaran sehingga memungkinkan guru untuk mencapai hasil yang optimal. Rancangan Penelitian adalah pokok-pokok perencanaan seluruh penelitian yang tertuang dalam satu kesatuan naskah secara ringkas, jelas dan utuh. Rancangan penelitian dibuat dengan tujuan agar pelaksanaan penelitian dapat dijalankan dengan baik, benar dan lancar. Untuk penelitian ini penulis memilih rancangan penelitian tindakan yang disampaikan oleh Depdiknas (2016:12).

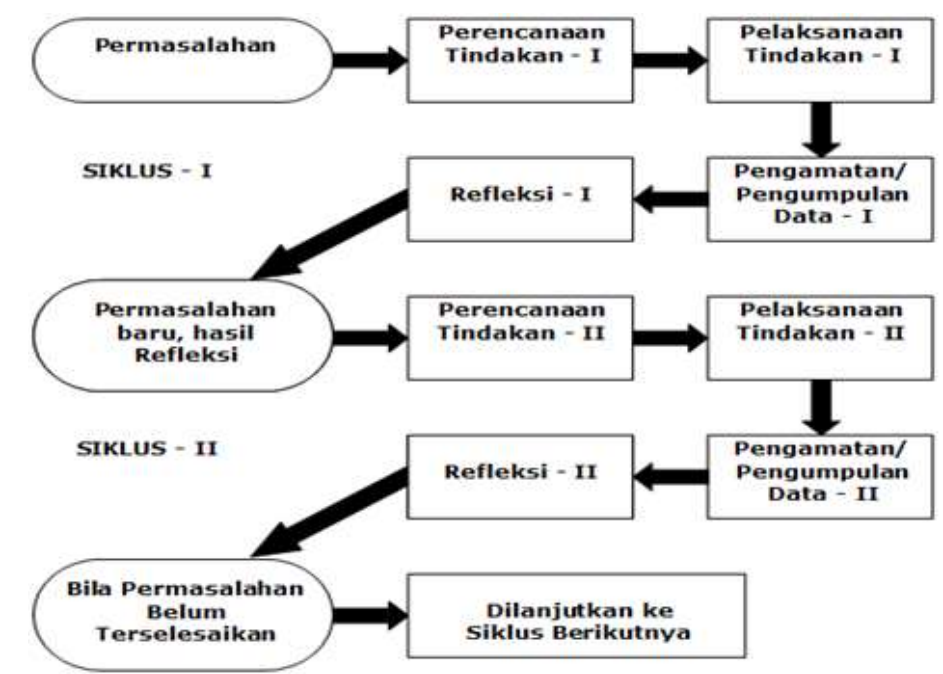

Gambar 1. Rancangan Penelitian

Penelitian Tindakan Kelas yang dilakukan guru selaku peneliti dimaksudkan untuk membenahi kualitas proses dan hasil belajar siswa. Apabila belum maksimal dan tidak sesuai dengan harapan, guru harus melakukan perbaikan dimana tempat permasalahan tersebut terjadi. Peneliti menemukan permasalahan belum tuntasnya prestasi belajar geografi pada siswa kelas XI.IPS 1 semester II tahun pelajaran 2019/2020 di SMA Negeri 1 Kuta sehingga kelas tersebut ditetapkan sebagai subjek dalam penelitian ini. Kelas XI.IPS 1 semester II tahun pelajaran 2019/2020 di SMA Negeri 1 Kuta terdiri dari 36 orang dengan jumlah lakilaki 10 orang dan perempuan 26 orang. Objek penelitian merupakan sebuah alternatif tindakan yang dimanfaatkan untuk menghasilkan perbaikan yang diinginkan. Dari tindakan tersebut peneliti mendapatkan data yang diinginkan. Karena itu objek penelitian perlu ditetapkan yaitu peningkatan prestasi belajar geografi siswa kelaas XI.IPS 1 semester II tahun pelajaran 2019/2020 di SMA Negeri 1 Kuta setelah pelaksanaan metode brainstorming 
dengan penugasan. Untuk menuntaskan tahapan tindakan dari perencaaan, pelaksanaan, observasi, dan refleksi akan dilakukan penentuan batas waktu sesuai perencanaan. Agar lebih sistematis dan terencana, peneliti perlu menyusunnya menjadi jadwal yang sistematis dan terusun dengan baik. Dalam penelitian ini jadwal pelaksanaan tindakan akan dilakukan dari bulan Januari sampai Mei tahun 2020.

Hasil belajar yang diperoleh siswa setelah pelaksanaan tindakan didapat peneliti melalui tes prestasi belajar. Tes yang digunakan telah terangkum dalam Rencana Pelaksanaan Pembelajaran yang terdapat pada lampiran. Peneliti melakukan pengolahan menggunakan statistik deskriptif. Selain itu statistik deskriptif juga berfungsi menyajikan informasi sedemikian rupa, sehingga data yang dihasilkan dari penelitian dapat dimanfaatkan oleh orang lain yang membutuhkan. Sehubungan dengan data diperoleh berbentuk angka, maka analisis data dilakukan secara deskriptif kuantitatif

\section{HASIL DAN PEMBAHASAN}

\section{Hasil Deskripsi Awal}

Pelaksanaan yang dilakukan dalam kegiatan awal diperoleh data yaitu, ada 7 orang $(19,44 \%)$ yang memperoleh nilai di atas KKM, 7 orang $(19,44 \%)$ yang memperoleh nilai sesuai KKM dan ada cukup banyak siswa yaitu 22 orang $(61,11 \%)$ yang memperoleh nilai di bawah KKM. Ketidakberhasilan tersebut banyak dipengaruhi oleh faktor ketidaksiapan guru dalam membuat perencanaan, profesionalisme guru dalam melaksanakan pembelajaran dan kesiapan guru dalam mempelajari keilmuan-keilmuan yang mesti ditetapkan dalam melaksanakan proses pembelajaran. Kelebihan yang telah diperbuat adalah peneliti sebagai guru IPS di SMA Negeri 1 Kuta telah berupaya semaksimal mungkin agar peningkatan mutu pendidikan di sekolah ini dapat berjalan sesuai harapan.

\section{Hasil Deskripsi Siklus I}

Analisis yang dapat disampaikan pada Siklus I adalah 11 orang $(30,56 \%)$ yang memperoleh nilai di atas KKM, 15 orang $(41,67 \%)$ yang memperoleh nilai sama dengan KKM dan 10 orang $(27,78 \%)$ yang memperoleh nilai di bawah KKM. Analisis kuantitatif Prestasi belajar siswa siklus I sebagai berikut: Rata-rata (mean) pada siklus I sebesar 69,86. Median (titik tengahnya) sebesar 70,00. Modus adalah angka yang paling banyak setelah diurut. Angka tersebut adalah: 70,00. Banyak kelas $(K)=1+3,3 \times \log (N)=1+3,3 \times \log$ $36=1+3,3 \times 1,56=1+5,15=6,15 \rightarrow 6$. Rentang kelas $(\mathrm{r})=$ skor maksimum - skor minimum $=80-60=20$. Panjang kelas interval (i) $=$ Rentang Kelas dibagi Banyak Kelas $=$ 20 dibagi $6=3,33 \rightarrow 4$.

Tabel 1. Data Kelas Interval Siklus I

\begin{tabular}{ccccc}
\hline $\begin{array}{c}\text { No } \\
\text { Urut }\end{array}$ & Interval & $\begin{array}{c}\text { Nilai } \\
\text { Tepi }\end{array}$ & $\begin{array}{c}\text { Frekuensi } \\
\text { Absolut }\end{array}$ & $\begin{array}{c}\text { Frekuensi } \\
\text { Relatif }\end{array}$ \\
\hline 1 & $60-63$ & $59,5-63,5$ & 5 & 13,89 \\
2 & $64-67$ & $63,5-67,5$ & 5 & 13,89 \\
3 & $68-71$ & $67,5-71,5$ & 15 & 41,67 \\
4 & $72-75$ & $71,5-75,5$ & 8 & 22,22 \\
5 & $76-79$ & $75,5-79,5$ & 0 & 0,00 \\
6 & $80-83$ & $79,5-83,5$ & 3 & 8,33 \\
\hline & Total & & 36 & 100 \\
\hline
\end{tabular}




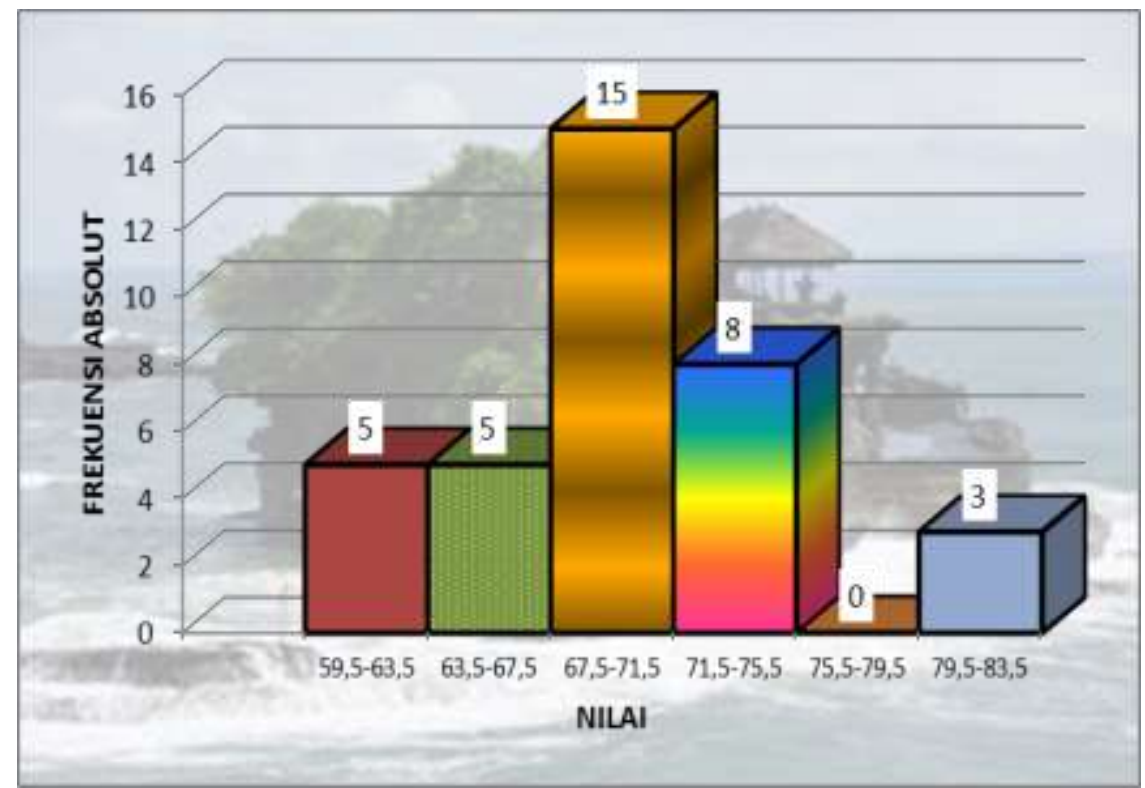

Gambar 2. Histogram Siklus I

\section{Hasil Deskripsi Siklus II}

Hasil yang diperoleh dengan pemberian tes prestasi belajar dapat dijelaskan: sudah 33 orang $(91,67 \%)$ yang memperoleh nilai di atas KKM dan 3 orang siswa $(8,33 \%)$ yang memperoleh nilai sama dengan KKM. Dengan hasil tersebut dapat dideskripsikan bahwa indikator keberhasilan penelitian yang diharapkan sudah terpenuhi. Rata-rata (mean) pada siklus I sebesar 81,14. Median (titik tengahnya) sebesar 82,50. Modus adalah angka yang paling banyak setelah diurut. Angka tersebut adalah: 85,00. Banyak kelas $(\mathrm{K})=1+3,3 \mathrm{x}$ $\log (\mathrm{N})=1+3,3 \times \log 36=1+3,3 \times 1,56=1+5,15=6,15 \rightarrow 6$. Rentang kelas $(r)=$ skor maksimum - skor minimum $=90-70=20$. Panjang kelas interval $(\mathrm{i})=$ Rentang Kelas dibagi Banyak Kelas $=20$ dibagi $6=3,33 \rightarrow 4$.

Tabel 2. Data Kelas Interval Siklus II

\begin{tabular}{ccccc}
\hline $\begin{array}{c}\text { No } \\
\text { Urut }\end{array}$ & Interval & $\begin{array}{c}\text { Nilai } \\
\text { Tengah }\end{array}$ & $\begin{array}{c}\text { Frekuensi } \\
\text { Absolut }\end{array}$ & $\begin{array}{c}\text { Frekuensi } \\
\text { Relatif }\end{array}$ \\
\hline 1 & $70-73$ & $69,5-73,5$ & 3 & 8,33 \\
2 & $74-77$ & $73,5-77,5$ & 5 & 13,89 \\
3 & $78-81$ & $77,5-81,5$ & 9 & 25,00 \\
4 & $82-85$ & $81,5-85,5$ & 17 & 47,22 \\
5 & $86-89$ & $85,5-89,5$ & 1 & 2,78 \\
6 & $90-93$ & $89,5-93,5$ & 1 & 2,78 \\
\hline & Total & & 36 & 100 \\
\hline
\end{tabular}




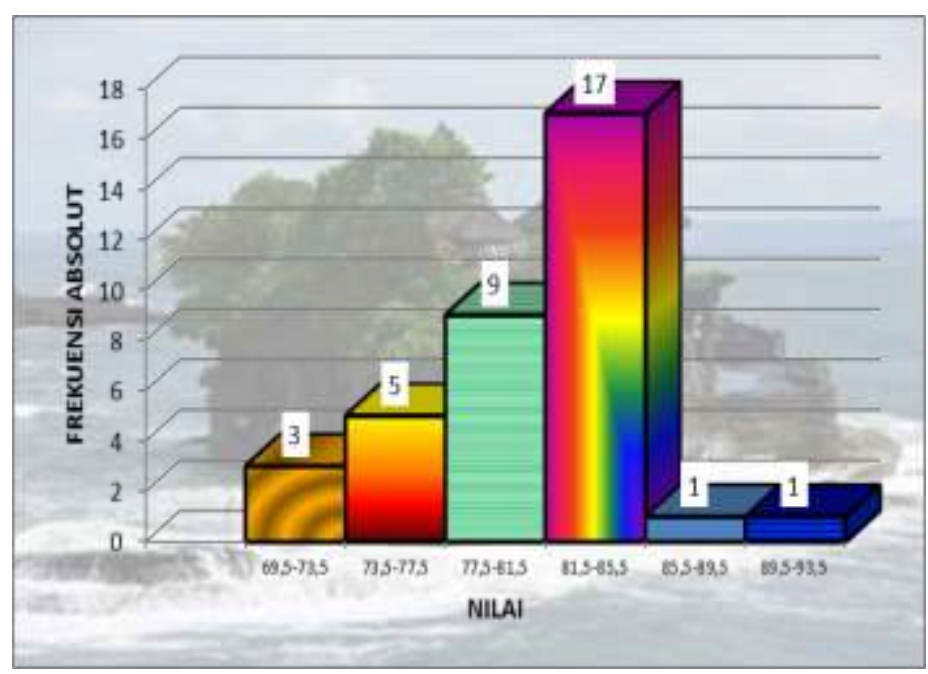

Gambar 3. Histogram Siklus II

\section{Pembahasan}

Kegiatan awal menghasilkan diperoleh nilai rata-rata geografi sebesar 66,06 dimana 7 orang $(19,44 \%)$ yang memperoleh nilai di atas KKM, 7 orang $(19,44 \%)$ yang memperoleh nilai sesuai KKM dan ada cukup banyak siswa yaitu 22 orang $(61,11 \%)$ yang memperoleh nilai di bawah KKM. Hasil yang rendah ini diakibatkan peneliti pada awalnya mengajar belum menggunakan model-model pembelajaran yang direkomendasi oleh ahli-ahli dunia. Peneliti lebih banyak berceramah, bercerita yang bukan-bukan dan mengajar kurang serius. Setelah dicek perolehan nilai siswa, ada banyak siswa memperoleh nilai di bawah KKM. Hasil ini sangat mengejutkan sehingga peneliti sebagai guru di SMA Negeri 1 Kuta merasa terpanggil untuk memperbaiki proses pembelajaran. Hal tersebut membuat peneliti mencoba pelaksanaan metode brainstorming dengan penugasan.

Dengan pelaksanaan pembelajaran telah diperbaiki pada siklus I ternyata hasil yang diperoleh baru mencapai rata-rata 69,86 dimana 11 orang (30,56\%) yang memperoleh nilai di atas KKM, 15 orang $(41,67 \%)$ yang memperoleh nilai sama dengan KKM dan 10 orang $(27,78 \%)$ yang memperoleh nilai di bawah KKM. Namun rata-rata tersebut masih juga di bawah indikator keberhasilan penelitian yang diharapkan walaupun dalam pelaksanaannya peneliti telah berupaya secara maksimal seperti memotivasi siswa, memberi penekananpenekanan, memberi arahan-arahan dan lain sebagainya. Kelemahan yang ada justru pada belum mampunya peneliti memahami secara mendalam kebenaran dari teori pelaksanaan metode brainstorming dengan penugasan yang digunakan dalam mengajar serta sintaks pembelajarannya.

Kelemahan-kelemahan yang masih tersisa pada pelaksanaan penelitian di siklus I, akhirnya peneliti proses pembelajaran diperbaiki agar diperoleh hasil yang lebih maksimal. Pelaksanaan yang sudah maksimal pada siklus II ini mampu meningkatkan prestasi belajar geografi mencapai nilai rata-rata 81,14 dimana 33 orang $(91,67 \%)$ yang memperoleh nilai di atas KKM dan 3 orang siswa $(8,33 \%)$ yang memperoleh nilai sama.Ternyata nilai tersebut sudah melampaui indikator keberhasilan penelitian yang diusulkan. Dari hasil tersebut kelebihan-kelebihan pelaksanaan pada siklus II yang telah disampaikan di atas menjadi dasar validitas. Kelebihan-kelebihan tersebut adalah: pelaksanaan metode brainstorming dengan penugasan sudah dilaksanakan dengan benar sesuai teori yang ada, minat siswa sudah meningkat akibat peneliti giat memberi motivasi-motivasi, antosiasme belajar peserta didik meningkat akibat tugas-tugas yang selesai dikerjakan, kegiatan belajar mandiri peserta didik sudah mampu diupayakan dengan baik. 


\section{KESIMPULAN DAN SARAN}

Kesimpulan dibuat berdasarkan data hasil penelitian, untuk menjawab rumusan masalah serta membuktikan hipotesis tindakan sehingga kesimpulan penelitian harus konsisten dan sesuai dengan rumusan masalah dan hipotesis tindakan. Hal-hal yang peru disampaikan di akhir penelitian ini adalah: Perolehan data awal yang rendah dan belum mencapai nilai kriteria ketuntasan minimal sesuai harapan, membuat peneliti harus giat mengupayakan cara agar masalah pembelajaran yang ada dapat diperbaiki sehingga peningkatan prestasi belajar geografi siswa dapat meningkat sesuai harapan. Setelah dilakukan penggantian metode pembelajaran dari metode pembelajaran yang konvensional menjadi metode pembelajaran yang konstruktivis yaitu metode brainstorming dengan penugasan, ternyata hasil yang diperoleh meningkat dari data awal dengan rata-rata 66,06 dengan ketuntasan belajar 38,89\%, pada siklus I rata-ratanya meningkat menjadi 69,86 dengan ketuntasan belajar $72,22 \%$. Pada siklus II rata-ratanya meningkat menjadi 81,14 dengan ketuntasan belajar $100 \%$ dan mencapai rata-rata sesuai kriteria ketuntasan minimal yang diharapkan. Dengan terjadinya kenaikan prestasi belajar geografi sesuai harapan maka dapat disampaikan bahwa rumusan masalah dan tujuan penelitian sudah tercapai. Dari perolehan bukti tersebut dapat disimpulkan juga bahwa hipotesis penelitian yang diajukan sudah dapat diterima. Jadi disimpulkan bahwa pelaksanaan metode brainstorming dengan penugasan dapat meningkatkan prestasi belajar geografi siswa kelas XI.IPS 1 semester II tahun pelajaran 2019/2020 di SMA Negeri 1 Kuta.

Berdasarkan hasil penelitian, maka dapat disarankan beberapa hal antara lain sebagai berikut: 1) Guru Geografi, hendaknya terus berusaha untuk meningkatkan kemampuannya dalam mengembangkan materi, menyampaikan materi, serta dalam mengelola kelas, sehingga kualitas pembelajaran yang dilakukannya dapat terus meningkat seiring dengan peningkatan kemampuan yang dimilikinya. 2) Guru hendaknya mau membuka diri untuk menerima berbagai bentuk masukan, saran, dan kritikan agar dapat lebih memperbaiki kualitas mengajarnya. 3) Guru harus lebih kreatif dan inovatif dalam menerapkan metode yans sesuai dengan tingkat kemauan siswa supaya pembelajaran lebih bervariasi dan tidak monoton menggunakan paradigma lama sehingga siswa tidak bosan.

\section{UCAPAN TERIMAKASIH}

Ucapan terima kasih disampaikan kepada Kepala SMA Negeri 1 Kuta dan Bapak/Ibu Guru SMA Negeri 1 Kuta

\section{DAFTAR PUSTAKA}

Amri, Sofyan. 2013. Peningkatan Mutu Pendidikan Sekolah Dasar dan Menengah. Jakarta: PT. Prestasi Pustakaraya.

Ardhi, Fauzi Usman. 2012. Skripsi. Implementasi Metode Pembelajaran Penugasan Sebagai Upaya Meningkatkan Aktivitas Dan Prestasi Belajar Mata Diklat Plc (Programmable Logic Control) SMK Muhammadiyah 3 Yogyakarta. Fakultas Teknik. Universitas Negeri Yogyakarta.

Aqib, Zainal. Cetakan Pertama Februari 2014. Model-model, Media, dan Strategi

Pembelajaran Kontekstual (Inovatif). Penerbit: Yrama Widya. Bandung.

Aunurrahman. 2017. Belajar dan Pembelajaran. Bandung: Alfabeta.

Bhakti, Ahmad Haris. 2017. Tesis. Pengaruh Strategi Pembelajaran Kooperatif Tipe STAD (Student Team Achievement Division) Dan Jigsaw Terhadap Prestasi 
Belajar Pendidikan Kewarganegaraan Ditinjau Dari Minat Belajar Siswa SMP Negeri Di Kecamatan Ngawi. Program Studi Teknologi Pendidikan. Program Pascasarjana Universitas Sebelas Maret. Surakarta.

Depdiknas. 2016. Membimbing Guru dalam Penelitian Tindakan Kelas. Jakarta: Pusat Pengembangan Tenaga Kependidikan Badan Pengembangan Sumber Daya Manusia Pendidikan dan Menjaminan Mutu Pendidikan

Habsari, Sri. 2015. Bimbingan \& Konseling SMA kelas XI. Jakarta: Grasindo.

Hakim, Thursan. 2015. Belajar secara Efektif. Penerbit: Pustaka Pembangunan Swadaya Nusantara. Jakarta

http://jcflowers1.iweb.bsu.edu/rlo/brainstorming1.htm)

Iriyanto, H.D. 2012. Hebat Gurunya Dahsyat Muridnya. Jakarta: Erlangga.

Masyitoh, Iim Siti. dkk. Model Pembelajaran Curah Pendapat Untuk Meningkatkan Partisipasi Dan Keterampilan Sosial Mahasiswa. Proceding of The 4th International Conference on Teacher Education; Join Conference UPI \& UPSI Bandung. Indonesia. 8-10 Nopember 2015. Universitas Pendidikan Indonesia.

Nyoto, Amat dan Made Wena. 2014. Bahan Ajar. Model-Model Pembelajaran. Panitia Sertifikasi Guru (Psg) Rayon 115. Universitas Negeri Malang.

Sukadi, 2015. Makalah. Metode Pembelajaran, Pengertian, Kelebihan, dan Kelemahannya. Program Pasca Sarjana. Pendidikan Sains Untad

Suprijono, Agus. 2013. Pendidikan Orang Dewasa. Dari Teori Hingga Aplikasi. Penerbit: Bumi Aksara. Jakarta.

Tirtonegoro, Sutratinah. 2015. Penelitian hasil belajar mengajar. Surabaya: Usaha Nasional.

Yamin, H. Martinis. 2013. Strategi dan Metode dalam Model Pembelajaran. Jakarta: Referensi (G. P. Press Group) 